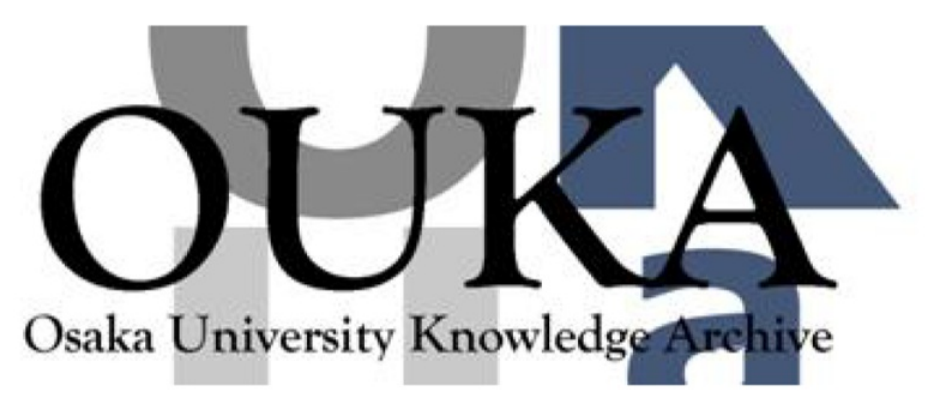

\begin{tabular}{|c|c|}
\hline Title & ミリ波車車間通信における信号伝搬特性 \\
\hline Author (s) & 和田，友孝；前田，慎；岡田，実 他 \\
\hline Citation & 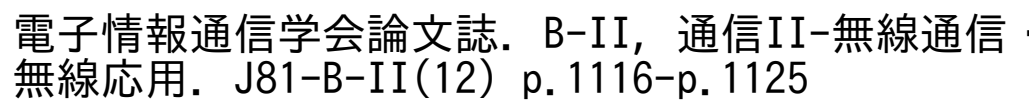 \\
\hline Issue Date & $1998-12$ \\
\hline oaire:version & VoR \\
\hline URL & ht tps://hdl. handle. net/11094/2890 \\
\hline rights & copyright@1998 IEICE \\
\hline Note & \\
\hline
\end{tabular}

Osaka University Knowledge Archive : OUKA

https://ir. Library. osaka-u. ac. jp/

Osaka University 
ミリ波車車間通信における信号伝搬特性

和田 友孝 ${ }^{\dagger}$ 前田 慎 ${ }^{\dagger}$ 岡田 実
小牧 省三†

\section{Theoretical Analysis of Propagation Characteristics in Millimeter Waves Inter-Vehicle Communication System}

Tomotaka WADA ${ }^{\dagger}$, Makoto MAEDA ${ }^{\dagger}$, Minoru OKADA ${ }^{\dagger}$, Katsutoshi TSUKAMOTO ${ }^{\dagger}$, and Shozo KOMAKI ${ }^{\dagger}$

あらまし 本論文では，車車問高速無線通信システムのマルチパス伝搬路特性を，レイトレーシング法を用い て解析している．まず交通量を考慮したミり波車車間伝搬路の伝搬路モデルを導出し，遅延プロファイルや受信 電力変動分布などのマルチパス伝搬路特性を検討する。つぎに，車車間通信のディジタル伝送において，車車間 伝搬路をライスフェージングチャネルとしてモデル化した場合の信号対雑音電力比（CNR）の確率密度関数を求 め, 平均ビット誤り率特性について理論解析を行う.これをもとに数值計算を行い, 所要平均ビッ卜誤り率を得 るための所要送信電力, 最大伝送可能速度, 交通量及びアンテナの大きさの間には密接な関係があることを明ら かにする。また，ダイバーシチ受信を行うことによる信号伝搬特性の改善効果についても検討を行う。その結果， フェージングによる影響を軽隇することができ信号伝搬特性の改善が図れることを明らかにしている.

キーワード ミリ波車車間通信, マルチパス, 遅延プロファイル, 交通量, 最大伝送可能速度

\section{1. まえがき}

近年，ミリ波を用いた車両間での高速無線通信システ ムについて，さまざまな検討が行われている[1]〜 [3]. ミリ波帯の電波はその波長がミリメートルオーダと 小さいため, アンテナや送受信回路を小さくでき，装 置の小型化が可能である.また，ミリ波では非常に広 い周波数帯域を利用することが可能であるため, 高速 ディジタル伝送の実現が可能となる.一方，ミリ波帯 の電波は大気吸収や降雨による減衰が大きいため [4] 遠距離伝送には適さないという問題があるが，車車間 通信においてはこのことが逆に容易に狭い範囲に電波 を閉じ込めることを可能にし，その結果，他ユーザか らの干渉を軽減することができ，周波数利用効率の向 上が期待できる。

しかし，車車間通信システムにおいては，車両や道 路, 建造物による反射から生じるマルチパスフェージ ングが問題になるが, マルチパスフェージングによる 受信振幅レベル変動により，ディジタル伝送時におけ

\footnotetext{
†大阪大学工学部通信工学科, 吹田市
}

Department of Communications Engineering, Faculty of Engineering, Osaka University, Suita-shi, 565-0871, Japan
るビット誤り特性は大きく劣化することが知られてい る [2]. 更に，広帯域ディジタル伝送時にはマルチパ スの各素波の伝搬遅延時間差が無視できなくなり, 波 形ひずみを生じて伝送特性が著しく劣化する，そのた め, ミリ波を用いた車両間での高速, 高品質な無線通 信の実現のためにはまず信号伝搬特性を解明する必要 がある．高速道路などの複数の車線が存在する道路へ 車車間通信を適用する場合には，信号伝搬特性が反射 体となる隣接車線の車両の交通量によりランダムに変 動するため，これらの影響を考慮に入れた解析が不可 欠である，基地局と移動局間の通信におけるマルチパ スフェージングに関して蛙非常に多くの解析が行われ ている [5]が, 車車間通信についての解析はほとんど 行われていない. 文献 [6]では, 車車間通信に扔ける マルチパス波の到来方向が一様であり，かつ水平面内 無指向性アンテナを用いていると仮定してマルチパス 波の振幅特性について理論解析を行っているが，アン テナの指向性は考慮されておらず，ミリ波を用いた車 車間通信の伝搬路モデルには適用できない。また，文 献 [7]では, 直接波と地面での反射波のみを対象とし, 隣接車線の車両による反射の影響结考虑していない。 
文献 [8]では，車両間の協調走行に扔いて地面での反 射波による影響が検討されているが，変動する交通量 は検討されていない。

そこで本論文では，高速道路を協調走行する車両の 交通量を考慮したミリ波車車間通信伝搬路の伝搬路モ デルを提案する，本提案モデルは道路の曲率や隣接車 線を走行する車両による反射の影響を考虑に入れたモ デルであり，交通量の変動による影響を解明すること ができ，また道路の曲率やアンテナの指向性による信 号伝搬特性の変化を解析できる，本論文では，本提案 モデルを用いて振幅変動特性や遅延プロファイルなど の基本特性を明らかにする。また，高速ディジタル伝 送時に扔ける平均ビット誤り率について数值計算を行 い，ミリ波車車間通信システムの信号伝搬特性を明ら がにる. 更に，ダイバーシチ受信を行うことによる 信号伝搬特性の改善効果についても検討を行う.

\section{2. ミリ波車車間通信伝搬路モデル}

図 1 に車車間通信の伝搬路モデルを示す．車線幅 $L_{r}$ の 2 車線高速道路に扔いて，同じ車線を走行する 2 車両間で無線通信を行う場合を想定する，車線は曲率 半径 $R$ のカーブであり，カーブの内側はコンクリー 卜側壁とする。カーブ外側でのガードレール等による 反射も考えられるが，ロープによるガードレール区間

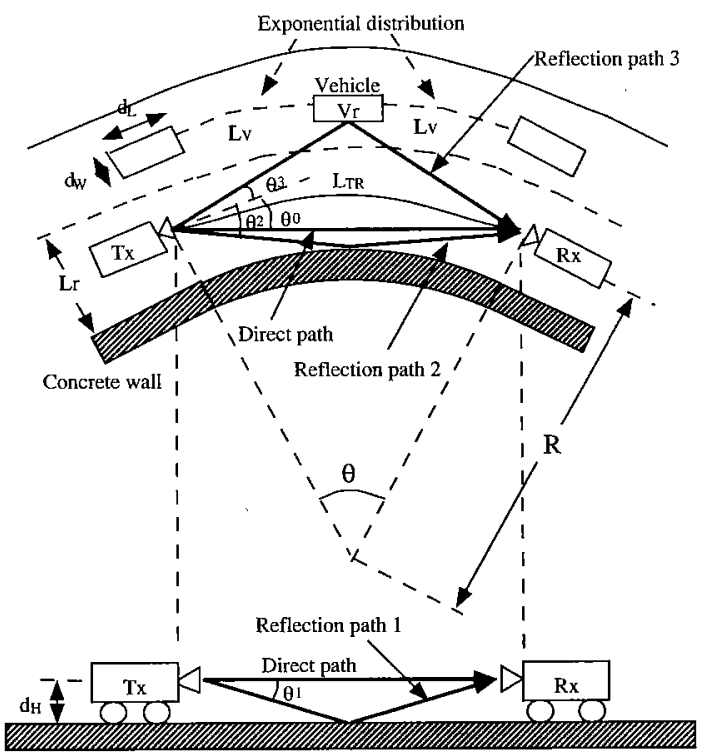

図 1 伝搬モデル

Fig. 1 Propagation model.
やガードレール不設置区間が存在すること, 反射面積 が側壁に比較し小さいこと, 計算を簡易化すること等 を考慮し，本解析では内側の側壁による反射のみを検 討の対象とする．このとき，送信車両 $T_{x}$ と受信車両 $R_{x}$ 間の道路に沿う距離を $L_{T R}$ とし, この間の多重 伝搬路として，直接波，1回反射成分として路面での 反射成分（反射波 1 ）, 道路側壁での反射成分（反射波 2), 隣接車線を走行吉る車両 $V_{T}$ での反射成分（反射 波 3）を考え，2 回以上の反射波成分については伝搬 路長が大きくなるのでその受信電力は小さいと考光ら れるため，無視することにする．更に，規則的な車両 のコーナに招ける回折波は, 車両側面に扔ける正規反 射波より大きくなることも想定されるが，一般的には 車両コーナは車両側面と比較し，不規則であることが 多いこと，並びに計算を簡易にするため，回折波の影 響を無視するものとする $[10]$ 。また，伝搬損の要因と して自由空間伝搬損とミリ波带酸素吸収損, 更に反射 波については反射面での吸収損も考慮する，また，一 般に速度の異なる車両間ではドップラーシフトが発生 するが，隣接車線を走行する車両と送受信車両との間 に速度差が生じてもドップラー周波数には影響がない ので，本解析ではドップラーシフトの影響はないもの と仮定する．また，さまざまな車長の車が走行すると 考光られるが，数值計算に要する処理時間が膨大とな るため, 車長を一定としたモデルで解析し, 反射車両 $V_{L}$ \&その車長 $d_{L}$, 車幅 $d_{W}$ とし, 反射車両の間隔 $L_{V}$ は平均值 $1 / \lambda_{v}$ の指数分布に従うランダム変数と する。ここで， $\lambda_{v}$ は車両の交通量を表し，本解析で は送受信車両と隣接車線の車両は一定の速度で走行す ると仮定すると，車両間隔の逆数が交通量となる．例 えば，ある一定の速度で車両が走行しているとすると， $\lambda_{v}=0.1 \mathrm{~m}^{-1}$ の場合, 平均 $10 \mathrm{~m}$ 顿きに 1 台の反射車 両が存在し, $\lambda_{v}=0.01 \mathrm{~m}^{-1}$ の場合, 平均 $100 \mathrm{~m}$ おき に1台の反射車両が存在する状態を表す。つまり， $\lambda_{v}$ が大きいほど平均車両問隔が小さく車両が混んでいる 状態を表す。よって，1/ $\lambda_{v}$ は交通量が多い場合は小 さくなり，少ない場合は大きくなる。また，送受信車 両 $T_{x}, R_{x}$ には路面から $d_{H}$ の高さに開口面が 1 辺 $l_{A}$ の正方形の同一の方形開ロアンテナが付けられて いるものとする。

この解析モデルは，車両の走行状態が一定に保たれ る，トラックが縦列に走行する，コンボイ走行や，西 る集団をなす車両群が走行する，プラトーニング走行 等に適用可能であると考えられる。一方，一般道では， 
車が右折, 左折を行う頻度が高く, 走行状態が一定で はないので, 本モデルの適用は難しい. 以後, 本論文 ではここでの解析モデルのみについて検討を行い,こ のような状況については报わないことにする。

次章では，このモデルを用いて信号伝搬特性の解析 を行う.

\section{3. マルチパス伝搬路特性}

\section{1 各パスの受信電力特性}

本節ではレイトレーシング法を用いて伝搬路特性に ついて理論解析を行う。レイトレーシング法は, 反射 面に対する送信点の鏡像を仮想的な送信点として受信 点に到達するパスを探す方法である [9]. ミリ波伝般 特性を解析する場合,ミリ波の直進性により光線近似 することができ，実測值と比較しても高い精度で伝搬 路を推定できるのでこの方法がよく用いられる [10].

送受信車両に付ける開口面が $l_{A} \times l_{A}$ である方形開 ロアンテナの放射角 $\theta_{i}$ 方向に対する指向性関数 $G\left(\theta_{i}\right)$ は

$$
G\left(\theta_{i}\right)=\frac{4 \pi l_{A}^{2}}{\lambda^{2}} \operatorname{sinc}^{2}\left(\frac{l_{A} \sin \theta_{i}}{\lambda}\right) \quad(i=0,1,2,3)
$$

で与えられる [11].ただし，

$$
\operatorname{sinc}(x)=\frac{\sin \pi x}{\pi x}
$$

と定義する。この方形開ロアンテナの指向性関数は 図 2 のようになる.アンテナの 1 辺の長さ $l_{A}$ が決ま れば，それに対応してアンテナの指向性を示す放射角 半值幅 $A$ が決定される. 周波数等に対する一般性を 向上させるため, 以下で洼, この半值幅 $A$ を用いて 表現する。

各伝搬路での送信電力に対する相対受信電力 $P_{r i}$ は 次式で与えられる。ただし， $P_{r i}$ の $i$ は 0 が直接波， 1 が反射波 $1 ， 2$ が反射波 $2 ， 3$ が反射波 3 をそれぞれ 表す.

$$
\begin{aligned}
& {\left[P_{r i}\right]_{\mathrm{dB}}=\left[\frac{\text { 各伝搬路での受信電力 }}{\text { 送信電力 }}\right]_{\mathrm{dB}}} \\
& \left.=[\text { 指向性関数 }]_{\mathrm{dB}}+\text { [自由空間伝搬損 }\right]_{\mathrm{dB}} \\
& \text { +[酸素吸収減衰 }] \mathrm{dB}+\text { [反射損 }] \mathrm{dB} \\
& =20 \log \left\{\frac{4 \pi l_{A}^{2}}{\lambda^{2}} \operatorname{sinc}^{2}\left(\frac{l_{A} \sin \theta_{i}}{\lambda}\right)\right\} \\
& +20 \log \left(\frac{\lambda}{4 \pi l_{i}}\right)-\gamma_{0} l_{i}+10 \log \rho_{g}
\end{aligned}
$$

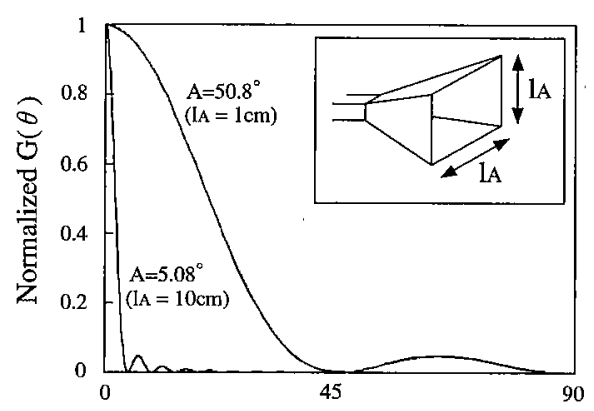

Angle of Radiation : $\theta$ (degree)

図 2 方形開ロアンテナの指向性関数

Fig. 2 Antenna directivity function of rectangular aperture horn antenna.

$+10 \log \rho_{w}+10 \log \rho_{v}$

$$
(i=0,1,2,3)
$$

ここで, $l_{i}$ は各伝搬路の経路長， $\theta_{i}$ は各伝搬路の放射 角, $l_{A}$ は方形開口アンテナの 1 辺の長さ, $\lambda$ はミリ波 の波長， $\gamma_{0}$ は酸素吸収隇衰係数であり， $\rho_{g}, \rho_{w}, \rho_{v}$ はそれぞれ路面, 道路側壁, 反射車画 $V_{r}$ の電力反射 係数である.

また，直接波の受信電力に対する各伝搬路での相対 受信電力 $P_{i}$ は

$$
\left[P_{i}\right]_{\mathrm{dB}}=\left[P_{r i}\right]_{\mathrm{dB}}-\left[P_{r 0}\right]_{\mathrm{dB}} \quad(i=0,1,2,3)
$$

と求めることができる.

\section{2 遅延プロファイル}

遅延プロファイルは各反射波の直接波に対する到着 遅延時間及び相対受信電力を求めることにより導かれ る.以下の解析では，送受信車両は等速度であると仮 定する.このとき，各伝搬路の信号遅延時間は光速 $c$ 及び各伝搬路の経路長 $l_{i}$ を用いて

$$
\tau_{i}=\frac{l_{2}-l_{0}}{c} \quad(i=0,1,2,3)
$$

と表される。ここで， $l_{i}$ は送受信機間距離 $L_{T R}$ と道 路の曲率半径 $R$ を用いて次式で与えられる。

$$
\begin{aligned}
l_{0}= & \left\{2 R^{2}\left(1-\cos \frac{L_{T R}}{R}\right)\right\}^{1 / 2} \\
l_{1}= & \left(l_{0}^{2}+4 d_{H}^{2}\right)^{1 / 2} \\
l_{2}= & \left\{4 R^{2}+\left(2 R-L_{r}\right)^{2}\right. \\
& \left.-4 R\left(2 R-L_{r}\right) \cos \frac{L_{T R}}{2 R}\right\}^{1 / 2}
\end{aligned}
$$




$$
\begin{aligned}
l_{3}= & \left\{4 R^{2}+\left(2 R+2 L_{r}-d_{W}\right)^{2}\right. \\
& \left.-4 R\left(2 R+2 L_{r}-d_{W}\right) \cos \frac{L_{T R}}{2 R}\right\}^{1 / 2}
\end{aligned}
$$

ただし， $l_{i}$ の $i$ は 0 が直接波， 1 が反射波 1,2 が反射 波 $2 ， 3$ が反射波 3 をそれぞれ表す。図 1 の伝搬路モ デルにレイトレーシング法を適用すると，各反射波の 伝般路が一意に決定される.アンテナ位置のオフセッ 卜はないと仅定すると, 各伝搬路の放射角 $\theta_{i}$ は送受 信機間距離 $L_{T R}$ と道路の曲率半径 $R$ を用いて

$$
\begin{aligned}
& \theta_{0}=\frac{L_{T R}}{2 R} \\
& \theta_{1}=\sin ^{-1}\left(\frac{2 d_{H}}{l_{1}}\right) \\
& \theta_{2}=\sin ^{-1}\left\{\frac{l_{2}^{2}+L_{r}\left(4 R-L_{r}\right)}{4 R l_{2}}\right\} \\
& \theta_{3}=\sin ^{-1}\left\{\frac{\left(4 R+2 L_{r}-d_{W}\right)\left(2 L_{T}-d_{W}\right)-l_{3}^{2}}{4 R l_{3}}\right\}
\end{aligned}
$$

と求まる。ここで， $\theta_{i}$ の $i$ は 0 が直接波， 1 が反射波 1 ，2が反射波 $2 ， 3$ が反射波 3 をそれぞれ表す.

反射波 3 の存在は反射車両 $V_{r}$ の有無によって決ま るので, 送受信車両と反射車両 $V_{r}$ との速度差が一定 であるとすると, 反射波 3 の存在する確率 $q$ は集合 平均的に反射車闭が隣接車線の反射位置に存在する確 率で,

$$
q=\frac{d_{L}}{d_{L}+\left(1 / \lambda_{v}\right)}
$$

と求められる，したがって，交通量がランダムに変動 すると, 反射波全部の数にこの確率 $q$ に従い変動する.

\section{3 信号対雑音電力比の確率密度関数}

マルチパスフェージング環境を考慮したミリ波車車 間通信システムの誤り率について理論的に解析する. まず反射波対直接波電力比（R/D (Reflection/Direct) 比）を求める. 平均 $\mathrm{R} / \mathrm{D}$ 比 $R_{r d}$ は直接波の受信電力 に対する各伝搬路の相対受信電力 $P_{i}$ の和を反射波 3 の存在確率で平均することにより，

$$
\begin{aligned}
{\left[R_{r d}\right]_{\mathrm{dB}} } & =\left[P_{1}+P_{2}+q P_{3}\right]_{\mathrm{dB}} \\
& =\left[P_{1}+P_{2}+\frac{d_{L}}{d_{L}+\left(1 / \lambda_{v}\right)} P_{3}\right]_{\mathrm{dB}}
\end{aligned}
$$

で求められる.

この平均 $\mathrm{R} / \mathrm{D}$ 比 $R_{r d}$ を用いて車車間伝般路をライ スフェージングチャネルにモデル化した場合の信号対
雑音電力比, CNR (Carrier-to-Noise power Ratio) の確率密度関数を求める. 受信信号波の瞬時 $\mathrm{CN}$ 比 $\gamma$ は

$$
\gamma=\frac{\rho^{2}}{2 \delta^{2}}
$$

となる，ここで， $\rho$ は受信信号波の包絡線， $\delta^{2}$ はガウ 又雑音電力を表す. 確率変数変換により $\gamma$ の確率密度 関数は

$$
\begin{aligned}
p(\gamma) & =p(\rho) \frac{d \rho}{d \gamma} \\
& =\frac{\delta^{2}}{\sigma^{2}} \exp \left(-\frac{2 \delta^{2} \gamma+A^{2}}{2 \sigma^{2}}\right) \cdot I_{0}\left(\frac{A \delta \sqrt{2 \gamma}}{\sigma^{2}}\right)
\end{aligned}
$$

となる.ここで， $I_{0}()$ は第 1 種 0 次変形ベッセル関数

$$
I_{0}(x)=\frac{1}{2 \pi} \int_{0}^{2 \pi} \cdot \exp (x \cos \theta) d \theta
$$

である。また， $\sigma^{2}$ は反射波の平均電力であり， $\Gamma=$ $\sigma^{2} / \delta^{2}$ と卞. 更に, $A^{2} / 2$ 注直接波の平均電力であ り $A^{2} / 2 \sigma^{2}=1 / R_{r d}$ だから, 式(17)を $\Gamma$ と $R_{r d}$ を 用いて表すと,

$$
p(\gamma)=\frac{1}{\Gamma} \exp \left\{-\left(\frac{\gamma}{\Gamma}+\frac{1}{R_{r d}}\right)\right\} \cdot I_{0}\left(2 \sqrt{\frac{\gamma}{R_{r d} \Gamma}}\right)
$$

となる.したがって, 受信信号波の平均 $\mathrm{CN}$ 比 $\Gamma_{0}=\langle\gamma\rangle$ は

$$
\begin{aligned}
\Gamma_{0}= & \int_{0}^{\infty} \gamma p(\gamma) d \gamma \\
= & \frac{1}{\Gamma} \exp \left(-\frac{1}{R_{r d}}\right) \int_{0}^{\infty} \gamma \exp \left(-\frac{\gamma}{\Gamma}\right) \\
& \times I_{0}\left(2 \sqrt{\frac{\gamma}{R_{r d} \Gamma}}\right) d \gamma \\
= & \Gamma\left(\frac{1}{R_{r d}}+1\right)
\end{aligned}
$$

となる。また，受信信号波の平均 $\mathrm{CN}$ 比 $\Gamma_{0}$ \&，式 (15) と送信電力 $P_{T}$ を用いて

$$
\begin{aligned}
\Gamma_{0} & =\frac{P_{r 0}+P_{r 1}+P_{r 2}+q P_{r 3}}{k T B F} P_{T} \\
& =\frac{P_{r 0}\left(1+R_{r d}\right)}{k T B F} P_{T}
\end{aligned}
$$

とも表される.ここで, $P_{r i}$ は送信電力に対する各伝 搬路の相対受信電力である.これに対し, 式 (15) で示 
される $P_{i}$ は直接波の受信電力に対卞る他の各伝搬路 の相対受信電力である.また, $k T B F$ は受信機の熱 雑音であり， $k$ はボルツマン定数， $T$ は受信機雑音温 度, $B$ 海無線信号の帯域幅, $F$ は受信回路の雑音指数 をそれぞれ表す．数值計算に用いたこれらの諸定数の

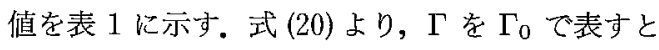

$$
\Gamma=\frac{\Gamma_{0}}{\left(1 / R_{r d}\right)+1}=\frac{R_{r d} \Gamma_{0}}{R_{r d}+1}
$$

となるので, 式 (19)のCN 比の確率密度関数 $p(\gamma)$ は, $\Gamma_{0}$ 及び $R_{\tau d}$ を用いて

$$
\begin{aligned}
p(\gamma)= & \frac{R_{r d}+1}{R_{r d} \Gamma_{0}} \exp \left[-\left\{\frac{\left(R_{r d}+1\right) \gamma}{R_{r d} \Gamma_{0}}+\frac{1}{R_{r d}}\right\}\right] \\
& \times I_{0}\left(\frac{2}{R_{r d}} \sqrt{\frac{\left(R_{r d}+1\right) \gamma}{\Gamma_{0}}}\right)
\end{aligned}
$$

と求められる.

\section{4 平均ビット誤り率}

ここでは, 変調方式として DBPSK (Differentially Binary Phase Shift Keying) を用い，受信側に㧍い て遅延検波を行うと仮定する.このとき, 瞬時 $\mathrm{CN}$ 比 が $\gamma$ のきのビット誤り率 $p_{e}(\gamma)$ は

$$
p_{e}(\gamma)=\frac{1}{2} e^{-\gamma}
$$

で与えられる [12]. 平均ビット謓り率 $P e$ は $p_{e}(\gamma)$ を $\gamma$ の統計量で平均することにより，

$$
\begin{aligned}
P_{e} & =\int_{0}^{\infty} p_{e}(\gamma) p(\gamma) d \gamma \\
& =\frac{1}{2(\Gamma+1)} \cdot \exp \left(-\frac{\Gamma}{R_{r d}(\Gamma+1)}\right)
\end{aligned}
$$

と表せる。よって，式 (22)の $\Gamma$ と $\Gamma_{0}$ の関係を用いて 受信信号の平均 $\mathrm{CN}$ 比 $\Gamma_{0}$ により表すと,

$$
\begin{aligned}
P_{e}= & \frac{R_{r d}+1}{2\left(R_{r d} \Gamma_{0}+R_{r d}+1\right)} \\
& \times \exp \left(-\frac{\Gamma_{0}}{R_{r d} \Gamma_{0}+R_{r d}+1}\right)
\end{aligned}
$$

となる.ここで，式(26)沛いて $R_{r d} \rightarrow \infty$ とすれば

表 1 熱雑音化関する諸定数

Table 1 Parameters of thermal noise.

\begin{tabular}{|c|c|}
\hline ボルツマン定数 $k$ & $1.38 \times 10^{-23} \mathrm{~J} / \mathrm{K}$ \\
\hline 受信機雑音温度 $T$ & $300 \mathrm{~K}$ \\
\hline 受信回路の雑音指数 $F$ & $10 \mathrm{~dB}$ \\
\hline
\end{tabular}

レイリーフェージングチャネルにおける平均ビット愦 り率 $P_{e}^{\prime}$ が求まり,

$$
P_{e}^{\prime}=\lim _{R_{r d} \rightarrow \infty} P_{e}=\frac{1}{2\left(\Gamma_{0}+1\right)}
$$

となる.ここで，ビット伝送速度と無線帯域幅が等し いと仮定すると, 平均 $\mathrm{CN}$ 比 $\Gamma_{0}$ とエネルギーコント ラスト $E_{b} / N_{0}\left(=\gamma_{b}\right)$ は等しくなり, 式 (26) と式 (27) で $\Gamma_{0}=\gamma_{b}$ とすれば $P_{e}$ と $P_{e}^{\prime}$ が求まる.

\section{4. 数值計算結果}

表 2 に数值計算で用いる諸定数の各值を示す。ミリ 波帯の周波数として, $60 \mathrm{GHz}$ 帯及び $74 \mathrm{GHz}$ 帯が検討 されているが，以下の検討では $60 \mathrm{GHz}$ 帯での伝般特 性についてのみ検討を行う。なお，74GHz 帯につい ては減衰係数は異なっているが，今回用いた手法は同 様に適用可能であると考えられる. また, 路面, 道路 側壁及び反射車雨の電力反射傩数は厳密には電波の入 射角や偏波面によって変化するが，この解析では一定 の值と近似しても妥当と考えられるので表 2 の值を用 いた [13].

\section{1 マルチパス伝搬路の遅延波特性}

図 3 に各伝搬路での送信電力に対する相対受信電力 特性を示す. 送受信機間距離 $L_{T R}$ が小さいときはア ンテナの指向性により反射波電力が抑えられるので, いずれのパスの相対受信電力も小さい.ところが送受 信機間距離が大きくなり反射波の放射角が小さくなる と反射波電力は抑えられなくなる。

また, 図 4 に遅延プロファイルの数值計算結果を示

\begin{tabular}{|c|c|}
\hline 周波数（ミリ波常） & $60 \mathrm{GHz}$ \\
\hline 波長 $\lambda$ & $5.0 \mathrm{~mm}$ \\
\hline 車線幅 $L_{r}$ & $4.0 \mathrm{~m}$ \\
\hline 車長 $d_{L}$ & $5.0 \mathrm{~m}$ \\
\hline 車幅 $d_{W}$ & $2.0 \mathrm{~m}$ \\
\hline 道路の曲率半径 $R$ & $500 \mathrm{~m}$ \\
\hline アンテナの高さ $d_{H}$ & $1.0 \mathrm{~m}$ \\
\hline 路面の電力反射係数 $\overline{\rho_{g}}$ & 0.5 \\
\hline 道路側壁の電力反射你数 $\rho_{w}$ & 0.5 \\
\hline 反射車雨の電力反射係数 $\rho_{u}$ & 0.9 \\
\hline 酸素吸収減衰係数 $\gamma_{0}$ & $0.015 \mathrm{~dB} / \mathrm{m}$ \\
\hline
\end{tabular}
す. 送受信機間距離 $L_{T R}$ が大きくなると, 直接波と 反射波の伝搬路長差が小さくなるので, 各反射波の遅 延時間は減少するのに対して, 相対受信電力はアンテ ナの指向性により変化する.

図 5 には放射角半值幅 $A$ をパラメータとしたとき の交通量 $\lambda_{v}$ に対する平均 $\mathrm{R} / \mathrm{D}$ 比 $R_{r d}$ の特性を示す。

表 2 数値計算で用いる諸定数

Table 2 Parameters of the simulation. 


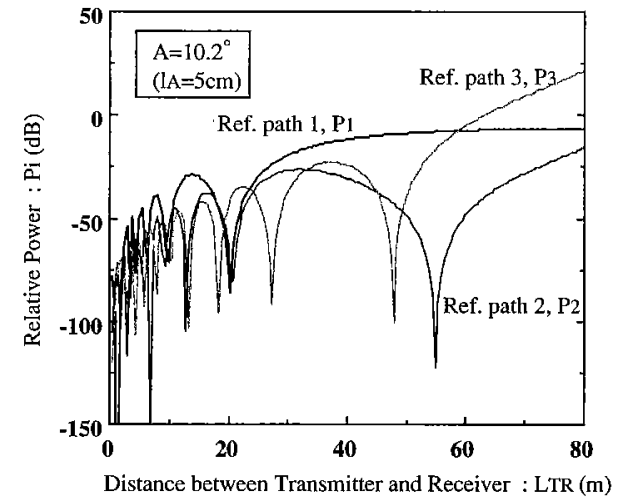

図 3 相対受信電力特性

Fig.3 Relative power against the distance between transmitter and receiver.

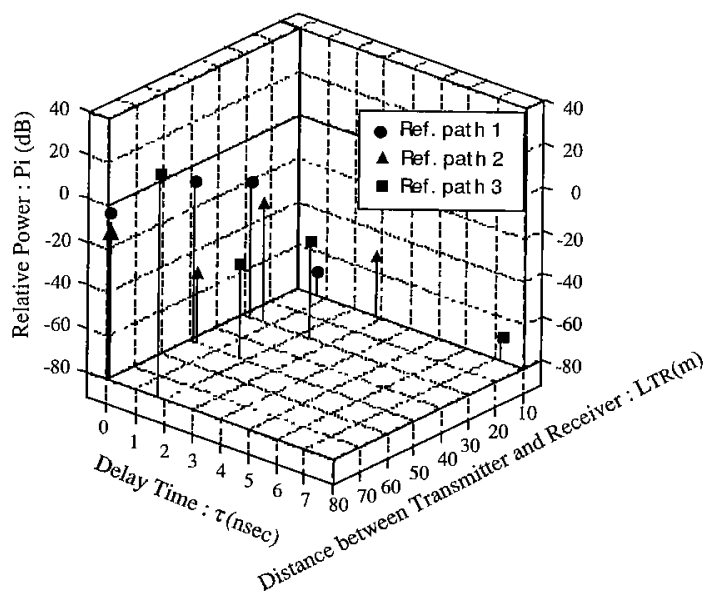

図 4 遅延プロファイル特性

Fig. 4 Delay profile performance.

送受信車両の車間距離 $L_{T R}$ と交通量 $\lambda_{v}$ との関係は, 車両の速度が一定であるとしているので，逆比例の関 係となる.したがって，交通量 $\lambda_{v}$ が大きくなるほど， 平均車間距離 $L_{T R}$ が小さくなり伝搬路長が小さくな るので, 式(15)の $P_{1}, P_{2}, P_{3}$ の值も小さくなる。 し たがって，平均 $\mathrm{R} / \mathrm{D}$ 比 $R_{r d}$ の值は小さくなることが わかる。これは送受信車両閒隔が小さくなるほど，ア ンテナの指向性により反射波電力が抑光られ，直接波 の影響が大きくなっているためである。この影響はア ンテナの大きさつまり指向性が鋭いほど顕著に表れ ている.

\section{2 平均 $\mathrm{CN}$ 比と平均ビット誤り率}

平均 $\mathrm{R} / \mathrm{D}$ 比梳交通量によって変化するので，交通

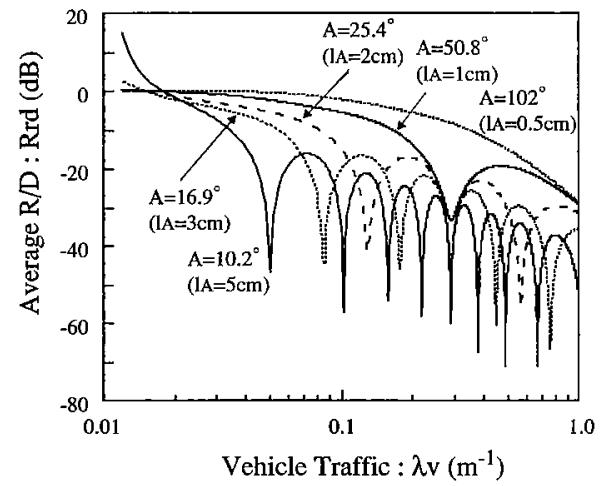

図 5 交通量に対吉平均 $R / D$ 比特性

Fig. 5 Average R/D against vehicle traffic.

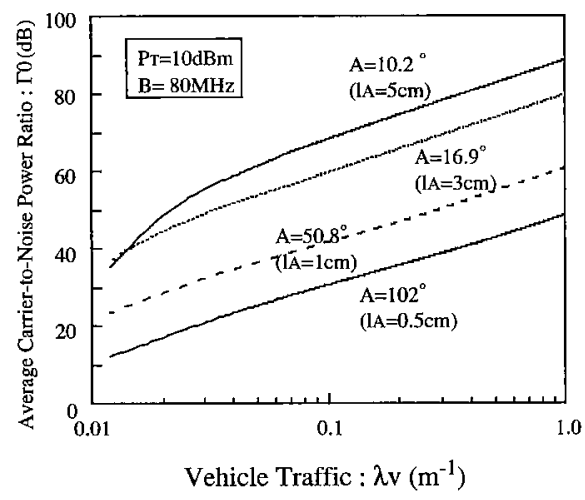

図 6 交通量に対安る平均 CNR 特性

Fig. 6 Average carrier-to-noise power ratio against vehicle traffic.

量と平均 $\mathrm{CN}$ 比の特性について検討する。式 (21)よ り, 平均 $\mathrm{CN}$ 比 $\Gamma_{0}$ 注送信電力 $P_{T}$ に比例し, 無線信 号の帯域幅 $B$ に反比例する. 図 6 に $L_{T R}=1 / \lambda_{v}$ のときの交通量 $\lambda_{v}$ に対する平均 $\mathrm{CN}$ 比特性を示す。 放射角半值幅 $A$ をパラメータとし, $B=80 \mathrm{MHz}$, $P_{T}=10 \mathrm{dBm}$ としている．交通量 $\lambda_{v}$ が大きくなる と送受信機間距離 $L_{T R}$ が小さくなるので送信電力に 対する直接波の相対受信電力 $P_{r 0}$ は大きくなるのに 対して反射波についてはその放射角が大きくなり，ア ンテナの指向性が鋭いため，反射波電力が抑元られて 平均 R/D比 $R_{r d}$ は小さくなる。 そして, 式 (21) から わかるように，平均 $\mathrm{CN}$ 比 $\Gamma_{0}$ は相対受信電力 $P_{r 0}$ と $\left(1+R_{r d}\right)$ の積に比例するので交通量 $\lambda_{v}$ に対する $\Gamma_{0}$ の振舞いは $P_{r 0}$ と $\left(1+R_{r d}\right)$ の総合によって決まる。 しかし，図 5 に示した $0.01 \mathrm{~m}^{-1}$ 以上の交通量 $\lambda_{v}$ で は $R_{r d}$ は十分 1 上り小さく, 平均 $\mathrm{CN}$ 比 $\Gamma_{0}$ はほほん 


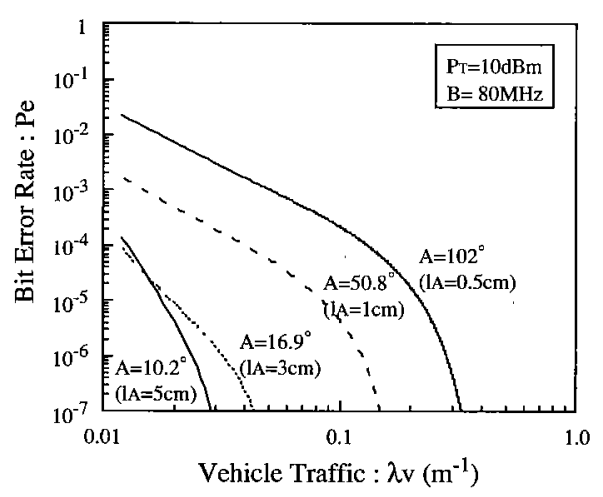

図 7 交通量に対する BER 特性

Fig. 7 Bit error rate against vehicle traffic.

ど $P_{r 0}$ に支配され， $\lambda_{v}$ の増加に伴い改善される。

つぎに, 図 7 に $L_{T R}=1 / \lambda_{v}$ のときの交通量 $\lambda_{v}$ に対する平均ビット誤り率の特性を示す，同図は放射 角半值幅 $A$ をパラメータとしている. 交通量 $\lambda_{v}$ が小 さいと，平均 $\mathrm{R} / \mathrm{D}$ 比が大きくなり反射波電力が大き くなるため，交通量 $\lambda_{v}$ 小さくしていくと誤り率は 急激比悪化してしまう。しかし，放射角半值幅 $A$ が 小さいほどアンテナの指向性が鋭くなり反射波電力が 抑えられるため, 䛊り率が急激に劣化するときの交通 量 $\lambda_{v}$ はより小さくできる.

\section{3 道路の曲率による影響}

図 8 に道路の曲率半径 $R$ をパラメータとした交通 量 $\lambda_{v}$ に対する平均ビット誤り率の特性を示す. 曲率 半径 $R=1,000 \mathrm{~m}$ の場合はほ深直線の道路と同様と考 えられ，交通量が大きくなるほど平均ビッ卜誤り率は 小さくなることが斿る。これに対して，曲率半径 $R$ が小さくなる，つまり曲がり具合が大きくなるにつれ て所要の誤り率を得るのに必要な交通量は大きくなり, 車間距離が小さくなければならないことがわかる。曲 率半径 $R$ が $300 \mathrm{~m}$ 及び $100 \mathrm{~m}$ の場合には, ある交通 量でいったん䛊り率が劣化し，更に交通量が大きくな ると誤り率が減少している。これは，アンテナの指向 性のメインローブの落ち込む方向に送受信アンテナが 向かい合ったために受信電力が減少したためだと考え られる。

\section{4 最適なアンテナの指向性}

図 9 に放射角半值幅 $A$ に対する平均ビット誤り率 特性学示す。また， $A$ に対応するアンテナの 1 辺の長 さ $l_{A}$ の值も示す. 同図は交通量 $\lambda_{v}$ をパラメータと し, $P_{T}=10 \mathrm{dBm}, B=80 \mathrm{MHz}$ としている.この

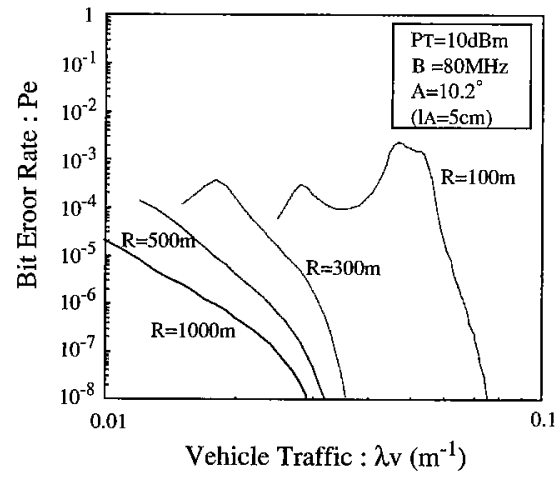

図 8 曲率半径をパラメータとした交通量に対する BER 特性

Fig. 8 Bit error rate against vehicle traffic as curvature parameters.

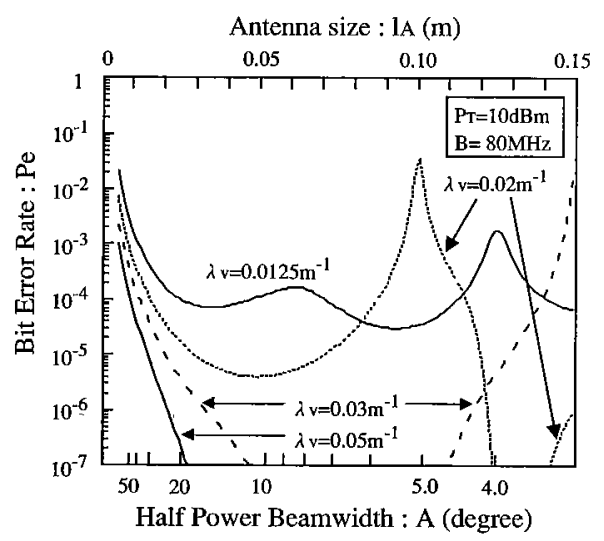

図 9 アンテナの放射角半值幅に対する BER 特性

Fig. 9 Bit error rate against half power beamwidth.

図加ら，交通量 $\lambda_{v}$ とアンテナの 1 辺の長さ $l_{A} に$ に り平均ビット愦り率は大きく変化していることがわか る. 例觉ば $\lambda_{v}=0.02 \mathrm{~m}^{-1}$ の場合, $l_{A}$ が約 $5 \mathrm{~cm}$ の ときに誤り率が小さくなっているが，それより小さく なると誤り率も劣化してしまっている。これは，指向 性が強くなると，その分送受信機間でメインローブか らのずれが生じるためである．また， $l_{A}$ が $10 \mathrm{~cm}$ を超 えると再び滅少しているが，これはアンテナの指向性 により隣接車線の車両による反射波 3 が大きくなるた め, 受信電力が大きくなることによると考光られる。 したがって，直接波による安定な通信を前提とすると， $l_{A}=5 \mathrm{~cm}\left(A=10.2^{\circ}\right)$ 付近で最適なアンテナの指向 性が得られることがわかる。したがって，アンテナの 指向性は交通量に合わせて適切に選ぶ必要があること 


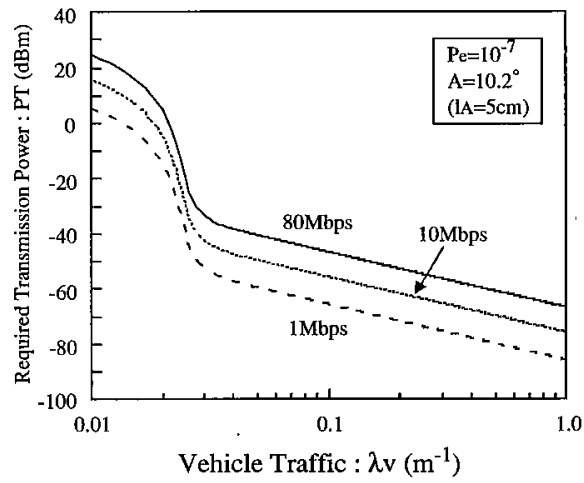

図 10 交通量に対与る所要送信電力特性

Fig. 10 Required transmission power against vehicle traffic.

がわかる。

\section{5 所要送信電力と最大伝送可能速度}

DBPSK の無線信号の帯域幅 $B[\mathrm{~Hz}]$ と伝送速度 $R[\mathrm{bps}]$ は

$$
R=B
$$

である．したがって，伝送速度を大きくすると必要な 無線信号の帯域幅が広くなるので, 受信回路の熱雑音 電力が大きくなり平均ビット誤り率は劣化する.

図 10 に交通量 $\lambda_{v}$ に対する所要平均ビット誤り率 $P_{e}=10^{-7}$ を得るために必要な所要送信電力 $P_{T}$ を示 す. 同図では伝送速度をパラメータとし， $A=10.2^{\circ}$ と する，交通量がある程度大きくなると，所要平均ビッ 卜誤り率 $P_{e}=10^{-7}$ を得るための所要 $\mathrm{CN}$ 比㟍急激 に小さくなるが，放射角半值幅 $A$ の值により急激な 変化をする交通量 $\lambda_{v}$ は異なる。よって, 図 10 に肪 いて所要平均ビット誤り率 $P_{e}=10^{-7}$ を得るための 所要送信電力 $P_{T}$ が急激に小さくなる交通量 $\lambda_{v}$ は伝 送速度には関倸なく同じになる。また，交通量 $\lambda_{v}$ が 大きいときはアンテナの指向性により反射波電力は大 幅に減少するため，受信電力は直接波電力に影響を受 ける。したがって，交通量 $\lambda_{v}$ が大きくなると所要平 均ビット誤り率 $P_{e}=10^{-7}$ を得るための所要送信電 力 $P_{T}$ は小さくなる.

つぎに，最大伝送可能速度について検討すると，式 (21) 及び式 (28) からわかるように, 平均 $\mathrm{CN}$ 比 $\Gamma_{0}$ は 送信電力 $P_{T}$ に比例し伝送速度 $R$ に反比例する.よっ て, 同じ条件にお当最大伝送可能速度は送信電力 $P_{T}$ 比例する。

図 11 に交通量 $\lambda_{v}$ に対する最大伝送可能速度を示

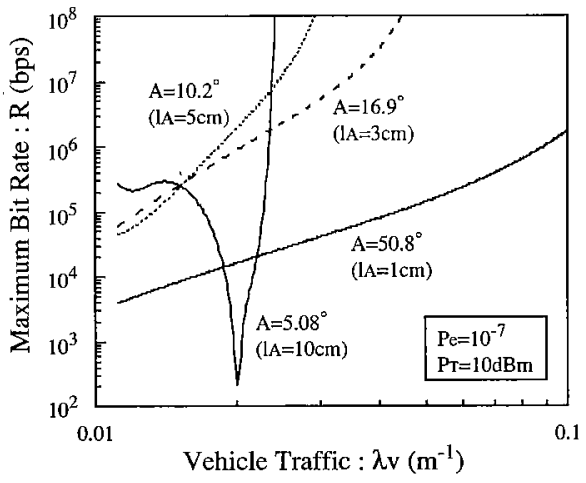

図 11 交通量に対与る最大㑂送可能速度特性

Fig. 11 Maximum bit rate against vehicle traffic.

す. 司図は放射角半值幅 $A$ をパラメータとし, 送信電 力 $P_{T}$ は $10 \mathrm{dBm}$, 所要平均ビット誤り率 $P_{e}=10^{-7}$ とする。交通量 $\lambda_{v}$ が大きくなると平均 $\mathrm{CN}$ 比 $\Gamma_{0}$ が 大きくなるので，平均ビット愦り率を同じに保ったま ま無線信号の带域幅 $B$ を大きくとれ, 最大伝送可能 速度が大きくなる。

しかし, 放射角半值幅 $A=5.08^{\circ}$ O場合, 交通量 $\lambda_{v}=0.02 \mathrm{~m}^{-1}$ 近辺で伝送速度が急激に減少してい る。これは, 交通量 $\lambda_{v}=0.02 \mathrm{~m}^{-1}$ の場合, 直接波 が指向性のメインローブとサイドローブの間に存在す る落込み点で受信されるため最大伝送可能速度が小さ くなっていると考光られる。

よって，交通量 $\lambda_{v}$ によって最も大きな最大伝送可 能速度をとりうるアンテナの大きさに㟍適值があ ることがわかる。しかし，この解析では符号間干渉に よって生ずる軽減不能誤りについて考慮していないた め, 実際には最大伝送可能速度はかなり制限されると 考えられる。

\section{5. ダイバーシチ受信の適用}

本章では，これまで解析した信号伝搬特性の改善の ために，図 12 のようなダイバーシチ受信の適用を検 討する。ここでは，受信側で選択ダイバーシチを行う ものとする。

効果的にダイバーシチ受信を行うためには，アンテ ナ A とアンテナBの間隔 $S_{A B}$ をある程度大きくする 必要がある，反射波の影響は地面反射波によるものが 大きいと考えられるので, 直接波と反射波 1 亿限定し て考光ると，その条件は

$$
\left|\left(l_{A 1}-l_{A 0}\right)-\left(l_{B 1}-l_{B 0}\right)\right| \geqq \frac{\lambda}{2}
$$




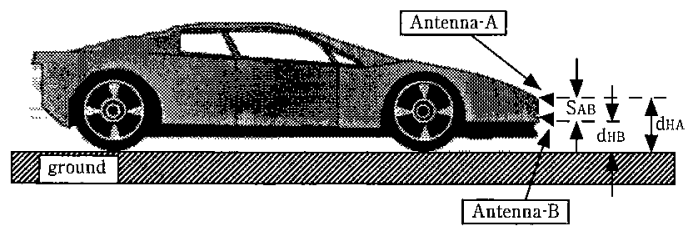

図 12 ダイバーシチアンテナ構成

Fig. 12 Diversity antenna configuration.

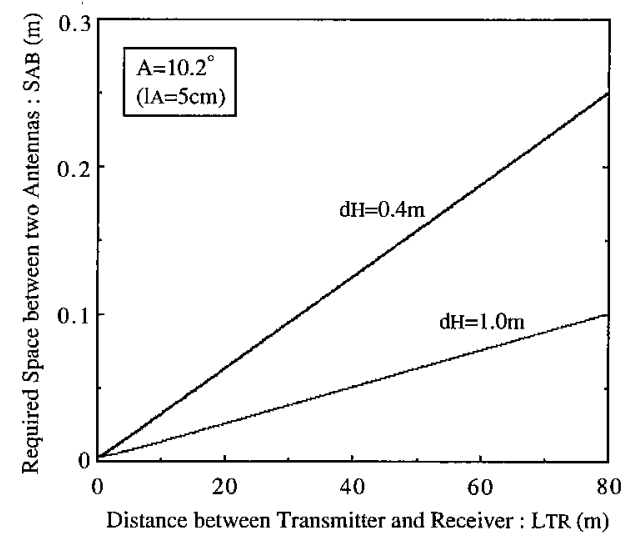

図 13 ダイバーシチ受信でのアンテナ間隔特性

Fig. 13 Required space between two antennas.

で与えられる、ただし， $l_{A 0}$ はアンテナAで受信する 直接波の伝搬路長， $l_{A 1}$ はアンテナA で受信する反射 波 1 の伝搬路長， $l_{B 0}$ はアンテナ $\mathrm{B}$ で受信する直接波 の伝搬路長， $l_{B 1}$ はアンテナ B で受信する反射波 10 伝搬路長である。

図 13 に式 (29)の条件を満たすために必要なアン テナ $\mathrm{A}$ とアンテナ $\mathrm{B}$ の間隔 $S_{A B}$ の特性を示す。同 図はアンテナの設置高 $d_{H}$ をパラメータとしている が， $d_{H}$ が小さくなると直接波と反射波 1 の伝搬路長 差が小さくなるため，ダイバーシチ受信に効果的なア ンテナの間隔 $S_{A B}$ は大きくなる。この図より，想定 している車間距離以内の通信では，バス，トラックな どの場合 $\left(d_{H}=1.0 \mathrm{~m}\right)$ 㹥 $15 \mathrm{~cm}$ 程度, 乗用車の場合 $\left(d_{H}=0.4 \mathrm{~m}\right)$ 注 $30 \mathrm{~cm}$ 程度アンテナの間隔をとればダ イバーシチ受信の効果が期待できる.

図 14 にはダイバーシチ受信における受信 CN 此の 累積分布を示す，比較のために，単一受信の場合も示 す。この図より，ダイバーシチ受信を行うことにより， $99 \% の$ 信頼性を得るための CN 比が約 $12 \mathrm{~dB}$ 改善でき， 信号伝搬特性の改善が図れる。

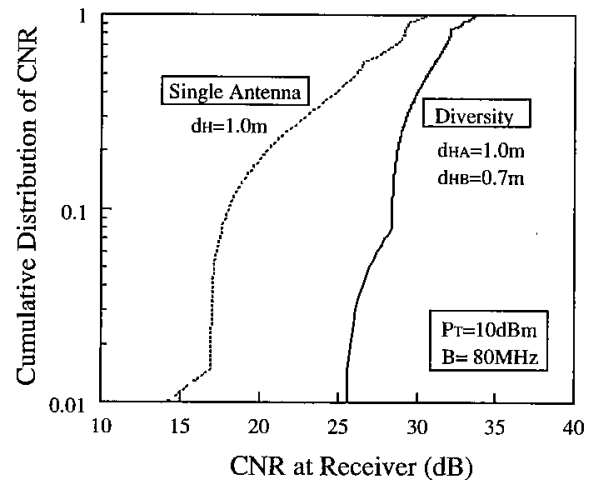

図 14 受信 CNR の累積分布特性

Fig. 14 Cumulative distribution of carrier-to-noise power ratio.

\section{6. むす び}

本論文では，ミリ波車車間通信システムにおける車 車間伝搬路について交通量を考慮してモデル化を行っ た，道路の曲率やアンテナの指向性による影響安調べ るために，遅延プロファイルを定義し，それから平均 $\mathrm{R} / \mathrm{D}$ 比とその交通量との関係を明らかにした，その結 果，交通量が大きくなるとアンテナの指向性により反 射波電力が抑えられ，平均 $R / D$ 比は大幅に減少する ことがわかった。更に，受信波統計モデルとしてライ スモデルを導入して，受信波の包絡線の確率密度関数 を導出し, 平均ビット愦り率について解析を行った。 また，平均ビット愦り率，送信電力及び伝送速度の関 係について明らかにした，その結果，交通量が大きく なると直接波の送信電力に対する相対受信電力が大き くなり平均 $\mathrm{CN}$ 比が大きくなるので所要送信電力は減 少し，最大伝送可能速度は増大寸ることがわかった。 また，アンテナを大きくして指向性を鋭くすればする ほど最大伝送可能速度が大きくなるわけではなく，逆 に伝送速度が大きく劣化する現象が起こる．この影響 を回避するためには，アンテナのサイズを適切に選ぶ 必要があり，その值法交通量に依存することが明らか となった．更に，ダイバーシチ受信を行うことにより， 信号伝搬特性の改善が図れることを示した。

今後は，送受信車両速度差によるドップラーシフト も含めた信号伝搬特性の解析，及び刻久と変化する車 両の走行状態の時間的変化, 蔇びに車雨コーナに㧍け る回折波, 散乱波考慮した解析を行う必要がある.

謝辞 本研究を進めるにあたり，御助言をいただい 
た三菱電機（株）産業システム研究所の深江唯正氏， 野田晋作氏，並びに日ごろ御討論いただく大阪大学工 学部通信工学科小牧研究室の各位に深謝いたします。

$$
\text { 文献 }
$$

[1] T. Tank, N. Yee, and J.P. Linnartz, "Vehicle-to-vehicle communication for AVCS platooning," IEEE Veh. Technol. Conf. VTC'94, pp.448-451, June 1994.

[2] R. Verdone, "Time and frequency selectivity effects in vehicle-to-vehicle communications at $60 \mathrm{GHz}$," IEEE Veh. Technol. Conf. VTC'94, pp.1780-1784, June 1994.

[3] O. Andrisano, D. Dardari, and R. Verdone, "Code division and time division multiple access networks for vehicle-to-vehicle communications at $60 \mathrm{GHz}$," IEEE Veh. Technol. Conf. VTC'94, pp.1859-1863, June 1994.

４4］内藤喜之，“マイクロ波・ミリ波工学,”コロナ社，1986。

[5] M. Schwartz, W.R. Bennett, and S. Stein, "Communication systems and techniques," pp.343-415, McGraw-Hill, Inc., 1966.

[6] A.S. Akki, "Statistical properties of mobile-to-mobile land communication channels," IEEE Trans. Veh. Technol., vol. 43 , no. 4, pp.826-831, Nov. 1994.

[7] R. Verdone, "Performance evaluation of R-ALOHA for inter-vehicle communications at millimeter waves," IEEE Proc. PIMRC'96, vol.1, pp.658-662, Oct. 1996.

[8] T. Tank and J.P. Linnartz, "Vehicle-to-vehicle communications for AVCS platooning," IEEE Trans. Veh. Technol., vol. 46, no. 2, pp.528-536, May 1997.

[9] T. Imai and T. Fujii, "Indoor micro cell area prediction system using raytracing for mobile communication systems," IEEE Proc. PIMRC'96, vol.1, pp.24-28, Oct. 1996.

[10] T. Manabe, "Fundamentals of millimeter-wave propagation," MWE'96 Microwave Workshop Digest, pp.501510, Dec: 1996.

[11］後藤尚久, “図説・アンテナ,”電子情報通信学会, 1995 .

[12] S. Stein and J.J. Jones, “現代の通信回線理論,”森北出版, 1991.

[13] 山本克則, 堀越清視, 丸山則義, 佐藤勝善, 真鍋武嗣, 井 原俊夫, “6 $60 \mathrm{GHz}$ 滞ミリ波㨟線 LAN システムの研究，"電 学計測研究資, vol.IM-95, no.41, pp.73-82, 1995.

(平成 10 年 3 月 2 日受付, 6 月 8 日再受付)

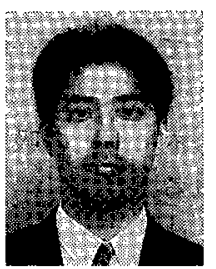

\section{和田 友孝 （学生員）}

平 7 阪府大・工・電気卒. 平 9 同大大学 院工学研究科博士前期課程了. 現在, 阪大 大学院工学研究科博士後期課程在学中. ペクトル拡散通信方式，車車間通信システ $\triangle$ の研究に從事. IEEE 学生員.

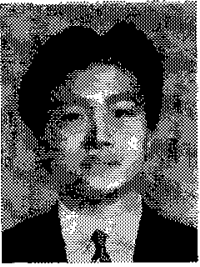

\section{前田＼cjkstart慎（学生員）}

平 9 阪大・工・通信卒. 現在, 同大大学院 工学研究科博士前期課程在学中. 車車間・ 路車間通信システムの研究に従事.

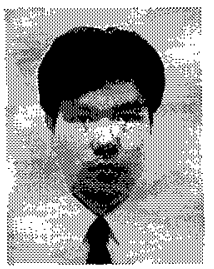

\section{岡田 実 (正員)}

平 2 電通大・電気通信・通信卒. 平 4 阪 大大学院工学研究科博士前期課程了. 現在, 同大・工・通信・助手.工博。移動通信に おける信号処理，符号化変調に関する研究 に従事. IEEE 会員.

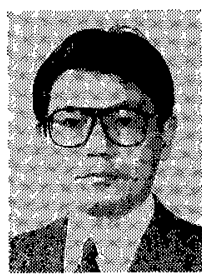

\section{塚本 勝俊 （正員）}

昭 57 阪大 -工・通信卒. 昭 59 同大大学 院修士課程了，阪大・工・助手を経て，現 在, 同助教授. 工博. 光通信方式, 光電波 融合通信方式の研究に従事. 平 7 年度本会 論文賞受賞.

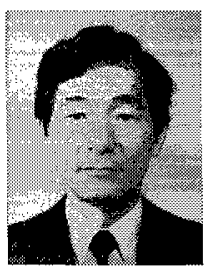

ア会員.

\section{小牧 省三 (正員)}

昭 45 阪大・工・通信卒. 昭 47 同大大学 院修士課程了. 昭 47 電電公社 (現, NTT) 入社. 平 2 阪大・工・通信・助教授，平 4 同教授.ディジタル無線通信方式並びに光 通信方式の研究比従事. 工博. 昭 50 本学 会論文賞, 平 5 同業䋶賞受賞. IEEEシニ 